\title{
Animation Education in Higher Education Institute of Canada
}

\author{
Xingqi Wang
}

Department of Animation College, Hebei Institute of Fine Art, Shijiazhuang, Hebei, 050700, China

Keywords: The resources of animation education, Inspired and explore teaching mode, Expression of ideas, Team spirit

\begin{abstract}
Canada has global reputation for her excellence in animation education and animation movie industry. Historically Canada starts developing her animation education and industry in just late 20th century; however, it quickly became the home of hundreds and thousands of brilliant animators and artists. This makes us wondering what is the secret to achieve such honor so quickly and so influentially. This article starts introducing the early days of Canadian higher animation education and then continuing explores its development, growth and evolution. [1]The author focuses her research and analysis on the characteristic of quality Canada higher animation education, academicals, theories and methodology, by introducing the effective grading policy and doing comprehensive comparison between Canadian and Chinese animation in higher education. Throughout researching, analysis, comparison and evaluation, the author tries to make the connection between marvelous Canadian higher education resources and the high demand from Chinese higher education, to serve and achieve sustainable and healthier Chinese higher animation education in the future.
\end{abstract}

\section{Canada General Situation of the Development of Animation Education in Colleges and Universities}

Canadian Higher Education. Canadian History and Current Situation of the Higher Education. The earliest history of the university of Canada can be traced back to 1636, it was the Catholic church to imitate Paris university created, in the form of Quebec theological seminary. After 1867, Canada became a federal state, higher education has made considerable progress, successively in accordance with the style of the university, such as Britain, France and Germany set up 14 universities, such as English in the university of Toronto, carleton university, and university and the university of Montreal, Quebec in French.

The all-round development of Canadian higher education really is at the end of world war ii of the five, the $60 \mathrm{~s}$ of the 20th century, the government passed legislation to transform all universities into public universities, and formed as the main body of public university, vocational education as the core of diversity and diversified pattern of higher education, to a large extent achieved higher education fair and open. Since then, the Canadian higher education under the government's strong support, the rapid development, to the ninety s of the 20th century, the Canadian higher education indicators have been in the forefront of the world's major developed countries, such as 1991, 18 to 24 age group received college education accounted for 22\%, second only to America's $23 \%$. In 1995, the higher education spending to 2.5\% of GDP, and 2.4\% in the United States. Starting in 1997, Canada has seven consecutive years by the United Nations development program rated as the most suitable for human habitation, the three indicators is of Paramount importance, namely, per capita income, life expectancy and education level. Canada scores the highest degree of education is a citizen. The Canada College (University), 92, 122 University College (University) College, colleges (College) 400, per capita education funds ranked first in the world, in fact, Canada has become one of the most developed country in the global education[2].

The Canadian Higher Education Management System. From the point of the system of higher education in Canada, can be divided into two major areas, namely, theoretical study and application or professional study. The former is generally provided by the university, while the latter has a college to complete. For now, the higher education system of Canada has such three parts: the university, university college, colleges. We cannot simply regard them as the classification of the 
level, in Canada, vocational education has always been highly attention. The relationship between them should be as a support each other, complement each other. What's more, the exchanges and cooperation between them is becoming more and more close, many universities will applied courses in the curriculum, but also due to the education of university of rich resources at university college achieve their diversity characteristics. Canadian university usually offer a three-year bachelor's degree in general and a four-year honours bachelor's degree, but also offer a four-year university college of university of bachelor's degree, but there are also more three years or a two-year associate degree.

Canadian higher education management system is mainly dominated by the government, that is to say, appropriate operating cost and shall be the responsibility of the national and provincial funds. But in Canada, the federal government level does not have a unified management of the national education affairs department, the ministry of education, all university directly by the provincial government is responsible for the management. For examination and approval of the provincial government may, according to law the province set up a public university and other institutions of higher education, to regulate the use of the name of the university approved standard, the degree of power and so on. Provincial government although bear the university most of the funds, but rarely in the internal affairs of the university of intervention and academic activities, in Canada, each university enjoys a high degree of autonomy, mainly displays in: autonomous enrolment, setting the professional and professional direction, setting the courses and credits, independently work out personnel distribution system, the independent employment staff, independent joint ventures and international communication and so on.

The university internal management system are generally composed of board of directors, the school administration and the academic committee. The board of directors is the highest authority in the university, is responsible for the hiring of the principal, make decisions on major issues for examination and approval of the budget and supervision of financial status; And administrator is the headmaster, its main responsibility is responsible for fund raising, hiring teachers, and establish the rules and regulations; Academic committee is the highest academic authority in the university, responsible for all matters concerning the teaching and academic activities. They do their job, help each other and restraining each other, forming a scientific, democratic and efficient operation mechanism.

Canada, the Characteristics of Higher Education. Canadian higher education is one of the most distinguished feature of the school location clear, the universities and colleges have their goal of talent training. The former mainly provides the basic theory of learning, focus on the academic research and knowledge innovation, responsible for undergraduate and postgraduate education. While the institute focuses on the application of cultivating practical talents social needed. [3] The rational allocation of education resources is set according to the requirements of social development, make society at the time of digestion talent to be able to get the universities and colleges can also be in the face of social needs to play their role better. Founded in Canada you can from scratch, apply for a undergraduate university, but almost no college application upgraded to undergraduate course. And our domestic that is keen on the phenomenon of "rise this" is actually talents cultivation orientation, ignoring the actual demand of the society, a kind of pursuing big and high, the result of the wrong view, resulting in the undergraduate graduate students do, specialized subject undergraduate students do the embarrassing situation, causing serious waste of social resources, especially education resources.

Another feature of Canadian higher education is in the advanced concept of "human-oriented". So-called "all for students, for all students, for all of the students" in our country many colleges and universities is just a slogan, in the practice of teaching system design, management, operation and rarely, but in Canada it is a kind of consensus, a system and a kind of action. Schools will tailor a training plan for students, provide a rich variety of courses and programs for students to choose from. In the aspect of management, set up student adviser, they will provide every student with learning and living services, provides a strong guarantee for students' success. The third feature of Canadian higher education is the diversification of financing channels. In general, Canadian 
universities and colleges of education funds have such five sources, namely, the provincial government funding, student tuition, federally funded, school-run industry and scientific research as well as the social institutions and private donations, etc. And the provincial government holds a large proportion of funding, the former President of york university orchid, maggic Donald (Lan Macdonald) once said, in seven of the last century, during the eighty s, he served as the principal, the government investment and tuition proportion $85 \%$ to $15 \%$. In recent 20 years, with the continuous development of higher education, the education group, school running cost is increasing, the government has also been unprecedented fiscal pressures, into less, now the ratio is roughly around $60 \%$ to $40 \%$. Government investment will fall.

But cause the increase of tuition fees, it is also a Canadian higher education faces new problems. Of course, the federal government will be funded by its unique way to university, mainly through a variety of research fund to provide funding for colleges and universities, the proportion of high, accounting for $80 \%$ of university research funding. As for the other fund-raising way, such as industry, scientific research and social service revenue and giving individuals and social institutions, and so on, his each universities are can, situation. In Canada's university of education strategy in general has obvious sense of industry, market and cost accounting. Set professional and curriculum changes with social and economic development needs, some of the project plan and implementation according to the industrialization operation, configuration of various educational resources to cost accounting. It also makes the school on the charging standards, a relatively flexible hot but not controlled by the government and regulation of professional on raising standards, such as law and medicine, annual tuition fees can be as high as $\$ 25000$, in order to solve the university finance. Canadian higher education also has a characteristic is widely recruit students, high fees for international students to a certain extent, ease the shortage of the funds can help university. As an immigrant country, each year to receive about 300000 international migrants in Canada, diversity and cultural diversity of democracy for its international education laid a good basis of social and psychological environment. Different nationalities, different color, different cultural background of students in study and communication together, not only can broaden their horizons, for their perfect personality and learn to understand tolerance. Canadian animation art are, in fact, show the style of freedom, of the rich connotation, cultural diversity and the country's immigration history, ethnic fusion of diverse social and cultural background and the environment are closely related[4].

Canadian Animation Education Situation in the Second Quarter. Animation History and Current Situation of the Education. Technically, the animation education history is not long in Canada, in the eighty s to formal establishment of animation specialty in universities and colleges. But they also is in the thirty years Canada into the world of animation education, its development speed and has the power to be reckoned with. , of course, in universities and colleges set up animation professional before, Canada had the exploration of the animation, time can be traced back to the early 20 s of last century. Walter at anfield, Harold PeiBoDi and Bert Cobb three artists can be said to be the animation art pioneers in Canada, although they did not leave any concrete works, but in their hearts for animation art is the most sincere, the most pure pursuit has been admired by later generations, become successors immortal spirit wealth. After first appeared on the Canadian history truly animators, he is Bryant, fredrik reinfeldt. Fleming has received a period of time in France based learning art, engaged in illustrator artist, director, actors, theatre, etc. Later, he came to the United States, with Tony sag and others rise this is short for Chinese college students rise undergraduate course examination, is specialized in Chinese education system level rise the undergraduate course school or professional students continue to study the examination system. Originally refers to the fundamental purpose of serving the people heart and soul of the communist party of China, in this article refers to the Canadian education to serve the students heart and soul of educational philosophy. Cooperation to create animated movies. At the time, they are in a very difficult situation, both in capital and technology in place and isolated, but the artist is always enthusiastic about animation art, persistent and insist, finally created a "smile", "twilight" and "goodbye baby state pavilion" and "giant killer jack" and so on a series of animation works, is the first Canadian animation art creation. These works on the production technology and modern 
animation has far, but as a pioneer, his artistic conception and artistic attainments still has on subsequent animation creation.

In 1939, the state Film bureau of Canada (the National Film Board of Canada, NFB) was set up, the rapid development of the Canadian Film including animation undoubtedly played a vital role. State film bureau under the Canadian communication of culture, is one of the 15 cultural institution, its purpose is: to become Canada's eyes, through the development of film industry, promotion of the country to witness the development history of Canada, reflect comprehensively the Canada and the life of the people. One is in its many duties of animation art creation and the development of animation industry management and finance. As a result, people usually think that the establishment of it also marks the animation industry, Canada officially started. Although the government departments, the state film bureau of film industry such as the exercise of executive power, but its management concept is very advanced and open, always adhere to the "encourage originality, emphasis on individual freedom and maintain team closely work together" incentive policy. [5]This has to do with Canada's entire social environment and cultural tradition are highly consistent.

NFB always respect the artist's creative thinking and individual style, it is because of such a policy, environment and atmosphere, the film bureau culture itself or to support a number of world-class excellent animation master, Norman McClaren (Norman Mclaren) and Caroline liv (Caroline Leaf) is the most outstanding representatives among them. It can be said that the Canadian animation talent the incubator is mainly comes from society, university is the cradle in the making. McClaren was the founder of the Canadian state film bureau animation department, all his life he created nearly 60 animated short, he is good at use the rhythm of light and shadow colours to create the rhythm of the film, by the rhythm and abstract images to express his feelings about life, or thinking of reality. These works often contains a profound philosophy, has won a total of 147 international animation award, and pushed the Canadian animation to the international stage. His value is not only hereat, in his animation creation at the same time, also pay attention to the cultivation of the talent, to the development of animation, Canada has laid a solid talent base. Carolyn live in Canada state Film bureau (the National Film Board of Canada NFB) is the official organization, Canada was founded in 1939, by the National committee of Film director with the nine insolvency \& public trustee's office officials management Film development. Joined the state film bureau in 1972, six years of 1974 to 1979, she created the married goose owl "Mr Sam sand deformation to record" and so on a series of works. These animations using the white sand beach on the glass box manufacturing imaging technique, not only have sand special meaning, at the same time in visual effects, aesthetic taste, image tension and dramatic conflicts get breakthrough in such aspects as literature and animation art in the quicksand of her perfect fusion, give a person the feeling that find everything new and fresh. [6]These works to soak her to human, social, the life and emotion of the profound understanding and comprehension, her influence is not only the international, and continued to the present.

In the early eighty $\mathrm{s}$ of the 20th century, animation professional began in Canada in the universities and colleges, many public universities and private colleges and universities have to open the animation specialty, the cradle of university began to academic animation talent. Mentioned before Canada said the characteristics of higher education, university of Canada of the strategy of running common sense of industry, market and cost accounting. Set professional and curriculum changes with social and economic development needs, some of the project plan and implement all operate according to industrialization. Actually the university and college in 1975 and 1977 received a total of 10 counts of film awards at home and abroad, establish the status of Carolyn in animation artists.

The Layout of the Animation Specialty and Scale. Compared with the United States, Japan and other countries, Canada's animation started late, but its competitor, with less than 30 years formed its own unique system of education, and has given rise to a powerful animation market, animation industry has a pivotal position in the world. Canada's animated wonder investors attracted a lot of culture, not only has attracted numerous animation lovers and learners. Canadian universities and colleges animation professional to become the first choice for many students from all over the 
world. There is no doubt that Canada has the world's best animation education, learning resources and the environment. At present, there are more than 10 universities in Canada started the animation specialty, and more than 30 specialized institute of animation, combined with many schools and institutions open short-term training, learning.

In the number of nearly 4000 people, many of the Animation College and Animation of the world's most prestigious education institutions, such as, Emily Carr Institute (Emily Carr Institute), Sheridan College (College) Sheridan, Canadian film and television Animation College, vancouver movie College, Institute of technology, one hundred (Centennial College), Banff Art center (the Banff Centre for the Art) and the National Animation Design center (the National Animation and Design Centre) and so on. The cultivation of the 4000 people scale compared with our domestic, indeed is not large, but it compared with other popular major training scale in Canada also can be regarded. These colleges and institutions in Canada and around the world each year conveying many outstanding animation talent, their knowledge, technology first-class, eye shot is open, creative spirit. To is known as "animation master cradle" Sheridan college as an example, this school is regarded as "animation industry development of the world's benchmark", especially in the college of computer animation specialty enjoys "Harvard college animation industry" the laudatory name, the student work frequently in the international animation contest awards such as Oscar, and cultivate excellent graduates from year to year by Hollywood studios to enlisted, etc. Many animation college in Canada to become the world first-class works of film and television animation talent and incubation base.

The New Trend of Animation Education Teaching. Seven, as is known to all, in the eighty s, even in the ninety s, the two-dimensional animation was all the rage, occupies a large number of television channels and broadcast time, the animated cartoon "Mickey Mouse and Donald Duck", "Jimmy and jerry") and other commercial animation almost become a sign of public entertainment, they are all kinds of household image, and derived a lot of cultural products. But along with the advance of technology, the three dimensional animation, with its incomparable advantage began to disrupt the original pattern of animation, it is on the vision more expressive and impact, and closely integrated with the film, to adhere to the market and the culture of magic, won the unlimited business opportunities and development.

Space. Professor chau on wah in his "several trends in the development of contemporary western cartoon" the article pointed out that: "the three dimensional animation has been widely recognized, by simulation with computer graphics, image study and learn as a special shape, texture, texture, photosynthetic efficiency, etc., in the virtual world of images generated shows amazing special effects and three-dimensional conquer the animation industry is the main reason." Such as the 1995 pixar's "toy story" in the 77 - minute running time, with the 1561 full computer generated $3 \mathrm{~d}$ lens, with realistic scene, magnificent visual effect and difficult animation technology makes the three-dimensional images of the rage, for attention. According to the personage inside course of study, with the advent of the digital age, $3 \mathrm{~d}$ computer animation and special effects in movies using proportion is more and more big, especially the special effects for animation created a more broad space for development, it has become Canada's animation industry, and animation education the latest indicator. There are statistics show that provinces such as Ontario, Canada, the computer animation and special effects industry's annual earnings has amounted to \$200 million to \$1.7, computer animation production for 18000 to 21600, the effects of content production annual output of 7400 to 9000 minutes. Computer animation company market earnings ratio is divided into: $16 \%$ from animation film, $45 \%$ from TV animation, $17 \%$ from commercial advertising; Special effects to make the division of the company's earnings ratio is: $44 \%$ from movies, $16 \%$ from TV show, $13 \%$ from commercial advertising.

Therefore, animation, film and television animation series constitutes the mainstream in the development of animation industry. To that end, the government's response in a timely manner and quickly. Their immediate adjustment, greatly reduced the $2 \mathrm{~d}$ animation broadcast channel and time, and even stop for $2 \mathrm{~d}$ animation creation of government funding. School adjustment also followed, in a growing number of colleges and universities, and increase the proportion of $3 \mathrm{~d}$ technology 
related courses, the top priority in the animation professional curriculum. In fact, Canada is among the first countries to explore computer animation in the world, in 1974, the world's first pure computer animation "hunger" Canadian director Peter ford, Peter Fold and in the Oscar nominated for the best animated feature film festival. Then, in 1997, Richard Kang Dai director $3 \mathrm{~d}$ clip made the Lhasa, and in Oscar nomination with advanced three-dimensional computer technology. In 2004, the state film bureau producer Chris rand les under Canadian animator Ryan, the story of Larkin produced a 14 minutes of three-dimensional film master save Ryan, its profound and extensive. Today, $3 \mathrm{~d}$ animation technology in Canada will remain high in the world, its biggest advantage is its technology research and development. The government of Canada and more than 60 countries and regions in the world has a cooperation agreement, to ensure that Canada animation for better utilization of human resources and technical resources. Their digital software company to develop a variety of $3 \mathrm{~d}$ image software is still widely used, for example, Houdini SESI company development and Maya.

Softimage software three giants, especially in the particles and dynamics has a high reputation. Eyeon company development base. [7]In the synthesis of PC platform software Digital Fusion, has been fitted with as Maya software synthesis. Discreet Logic software developed by Inferno, Flame, Flint series, set into, in a drawing and non-linear editing, and even can satisfy the requirement of the high definition TV production. And Corel development of a professional Painter and vector drawing software CorelDraw Graphics Suite, etc., are among the world's leading software. Therefore, Canada's university of animation education not only attaches great importance to the teaching of the three dimensional animation technology, also has high-quality software resources and the environment, to ensure the high quality of its teaching and leading.

\section{Canada Characteristics of Animation Education Pattern in Colleges and Universities}

The Animation Education Resource Advantage. The Strong Support of National Policy. First of all, Canada's animation industry can boom, competitor, in the increasingly competitive international market compete with animation industry such as the United States, the European powers, and with unique artistic taste and abundant connotation is famous in the international animation industry, it has to do with Canada's federal and state government to animation industry continued strong support are inseparable. The federal government has enacted a number of policies to support domestic cartoons and show them to build broad platform, such as the federal government to the domestic television made the animation playback time of strict proportion. To Teletoon animation channel is Canada's only a 24 hours the animation of the channel, the proportion of government regulations of domestic cartoons to the must be up to $60 \%$. In order to protect the local culture of Canada, as Canadian broadcasting and TV industry professional management institutions and telecommunications commission also specializes in system.

Booked a film and television program production and broadcast standard, its core is called the connotation of the "Canadian". So-called connotation, Canada is a evaluation index system, as to the content of the film and television production and producer raised specific requirement, and there are plenty of scoring points. All radio and television program production must conform to the connotation of standard, otherwise it will not be broadcast, is difficult to get government funding support. Writers, such as the program director, music production and so on all is Canadian, get the corresponding points, only if the score reaches more than eight points, in order to be in line with the requirement of the connotation. For radio and television media, in order to get the business license, must be in accordance with the provisions of the proportion of broadcast conform to the connotation of the "Canadian" program. According to statistics, at present in Canada with a total of 6500 radio and television agencies across the country, which the state has 2275, accounts for 35\%, with 4225 private, accounting for $65 \%$. But whether state-owned or private, they must abide by this rule, namely in the broadcast of all program about Canada itself content will account for $50 \%$ to $65 \%$; In prime time, the country's program must be accounted for half the time. In addition, the government also rules as long as it is in Canada as a legal representative of the company production and 
animation products abroad mainly involved in the Canadian broadcasting revenue, preferential can get a tax credit, this measure is also greatly stimulated the anime products exports. Such a series of policies and regulations in the very great degree for healthy and orderly development of domestic animation, Canada has provided a broad space, also for them to participate in international competition has laid a solid foundation. But it's worth noting that the government is to play the cartoon proportion of mandatory quotas at the same time, the content of the broadcast for animation seldom ask and intervention, which is also crucial to animation industry development. Government to intellectual property protection and encourage the policy of mutual confluence, free and independent creation provides creative animation production system and legal protection. In fact, these measures to protect the domestic animation industry at the same time, also keep and stabilize the animation education and creative talent team in Canada, so that they have a very big space.

The Canadian government to support another important policies and measures of the animation industry is to hold all kinds of large-scale cultural activities, such as animation film festival every year and the film and television products trade fair, through this platform to display their own animation achievement, promote their own animation products, attract various animation elite to join, in order to promote the further development of animation industry in Canada. Ottawa, for example, the famous international animation film festival for the biggest sponsor a cultural activity. Among the four major international film festival, Ottawa international animation film festival, personality is distinct, the features of the work of too commercial, emphasizing it have strong artistic feature and the humanities spirit non-commercial experimental animation, make consistent on the artistic characteristics of Canada's animation spirit is able to fully display. In particular the academic of experimental animation become a very active element in the film festival, such ideas and opportunities for student work undoubtedly will build the best display and exchange platform. In 1997, the Canadian students also creates the Ottawa animation festival, more support for the development of animation education in colleges and universities, provides students with the opportunity to exchange and animation producers. Such contacts and exchanges make colleges and universities not only understand the animation market movements, also make the innovation activity into the market, production, study and research of the relationship between effective links and further strengthened. In fact, these seemingly non-commercial cultural activities in promoting cultural influence and emphasis on the artistic creation of independence at the same time, also bring to Canada's cultural market.

This pay a huge business opportunities, and business strategies of cultural industries generated by the huge social benefit and economic benefit is one of Canada's successful experience of the animation industry.

The Pluralistic Way of Development Aid. Nearly 30 years, animation education in Canada was able to strong development, on the one hand, because have a good market prospects of guidance, on the other hand, sufficient development foundation education funds is also indispensable. Of course, the Canadian government support for animation education is in the great background of the government's education policy being carried out. Government-funded schools, and contributive proportion is higher, the basic solved the trouble back at home of the school, it is also hard to do it in many western countries. According to statistics, in 2012, Canada's education spending accounts for about 7\% of GDP, investment proportion is the first in the world. Government always adhere to the high investment of education policy, adhere to the commercial development of colleges and universities, is the central task of the colleges and universities teaching, to cultivate talents. School at the same time also for the implementation of the central task provides a solid material conditions, good teaching environment and advanced teaching equipment, it also have animation major education in colleges and universities in Canada. As is known to all, with advanced professional equipment practice teaching is the realization of modern animation necessary premise, such as university of Quebec, Canada has equipped with distributed parallel cluster computing system (Renderfarm rendering farm) in North America was the first to use the ready-made CPU, Ethernet and operating system composed of super computer, Canada's defense ministry also often to use this system to deal with many data. This alone, can make full of status and meaning of higher education 
in Canada. Powerful computer all the experiment provides a strong technical support for students, students of all sorts of artistic imagination are possible with the support of technology into a vivid, vivid visual images, and achieve the perfect combination of art and technology.

The Canadian government on high investment of higher education is embodied in university teachers' salary. According to the "New York times, April 3, 2012, according to the results of a survey in terms of wage income, in the sampling of the world's 28 countries, income of Canadian teachers was obviously higher than that of other countries, the top. Just into the university teacher pay, for example, the monthly salary of up to 5733 dollars. For Canadian university teachers is mean monthly salary is \$7196, excluding price and tax factors, basic fairly with the United States. The stability of the high level of income for morality of a high quality of teachers in colleges and universities in Canada, laid the foundation of talent in order to ensure the teaching quality. Even has a huge market like animation effects, can the enterprise gold professional few teachers. Instead, there is a lot of enterprise's technical elite to colleges and universities engaged in teaching and the creation of cooperation projects, making Canada the sustained and rapid development of college animation education reserves the energy of strong people.

Animation Teaching. Study Together. How to realize the close combination of production, is a modern university faces a challenge, also is the modern university must choose a path of sustainable development. The combination of production, not only can better play to the university social service function, but also can promote the university in its scientific research and personnel training reform and development. Long-term since, our country university is in a state of closed schools, professional set up and disconnect, talents training and social needs to cultivate talents and social docking on from the outside, lack of market situation and the law, even caused the serious waste of human resources.

Art and Technology and Development. Canada is an immigrant country, pluralism and diversity constitutes the appearance and characteristics of the culture. Canada is also a very open country, attaches great importance to the cultural communication and accommodation, all this in animation education and animation industry and other fields also have been revealed. The Canadian government has stressed the nationality of culture, the protection of local culture also has a series of policies, but they are in promoting Chinese culture at the same time also reveals the power of the foreign culture, therefore, it is the biggest feature is the original and production of animation theme is extensive, cultural diversity, interesting diversity, it is highly acclaimed in the international animation industry. Animation development process can be found throughout Canada, Canada itself, and from the United States, Japan, South Korea and other animation power of creative personnel is taken seriously.

\section{References}

[1] Dennis/ Sandi Jones. <Computer Animation: A Canadian Sensation>.[ J ]. Exportwise. Spring.2005

[2] Hyejin Yoon/ Edward J. Malecki. <Cartoon planet: worlds of productionand global production networks in the animation industry $>$.[ J ]. Industrial and Corporate Change. Volume 19. Number 1

[3] Hyejin Yoon<The Animation Industry: Technological Changes, Production Challenges and Global Shifts> .[ J ]. Industrial and Corporate Change. Volume 19. Number 1

[4] XuYing. Canada's history and current situation of the animation industry. "[J]. Journal of world movie. 2006.06

[5] Peng Xiang. Canadian animation development. [J]. Journal of fine arts. 2010.1

[6] Sun Jiacong. Draw lessons from foreign advanced ideas to promote healthy development of domestic animation education ". [J] yanbian party school of learning. 2011.5 
[7] Wei Lingong. "on the research of the development of the animation education pattern in colleges and universities". [D]. Wuhan university of technology. 2008.12 